\title{
炭素が存在する窒素ガス中でのケイ砂とアルミニウム の反応過程で生じる重量減少について
}

\author{
*梅 林正気 - 小林和夫 • 森光 穗 積* - 中 村光 徳* \\ $(*$ 九州工業技術試験所 $)$
}

ケイ砂とアルミニウム粉末の成形体を炭素の存在する窒素ガス中で $1500^{\circ} \mathrm{C}$ まで加熱し, $1400^{\circ} \mathrm{C}$ 以上で著しい重量の減少を認めた. 加熱中の重量の変化及び生成相の変化を調べ以下の結果を得 た。窒素ガス中に存在する炭素は，窒素中の酸素を一酸化炭素として固定し酸素分圧を下げるのに 極めて有効であった. $1400^{\circ} \mathrm{C}$ 以上で認められた重量の減少は, ムライト, $\mathrm{O}^{\prime}$ 相, $\mathrm{X}$ 相等の一酸化 炭素による還元，及び窒化ケイ素と $\alpha$-アルミナの反応による $\mathrm{SiO}(\mathrm{g})$ の生成によることが分った． $1500^{\circ} \mathrm{C}$ に招汀重量の減少速度は，放物線則によく適合した. 具体的な律速段階は不明であるが， 成形体中の pore structure が重量の減少速度に影響をもつことが明らかとなった.

(1978 年 11 月 8 日受付)

\section{The Weight Loss in the Reaction Process between Siliceous Sand and $\mathrm{Al}$ in $\mathrm{N}_{2}$ in a Presence of Carbon Material on Route of Gas Flow}

\author{
Seiki UMEBAYASHI, Kazuo KOBAYASHI, Hozumi MORIMITU* \\ and Mitunori NAKAMURA* \\ Government Industrial Research Institute, Kyushu, Tosu-shi 841
* Kyushu Industrial University, Fukuoka-shi 813
}

The compacts of the mixture of siliceous sand and $\mathrm{Al}$ were heated in $\mathrm{N}_{2}$ atmosphere in a presence of carbon material on the route of gas flow. The weight change of the compacts was measured by thermogravimetric apparatus from a room temperature to $1500^{\circ} \mathrm{C}$, and the phases in the compacts at various stages of heating were analyzed by using X-ray diffraction technique.

Nitriding of $\mathrm{Al}$ took place above about $500^{\circ} \mathrm{C}$ and its reaction rate increased at the melting point of $\mathrm{Al}\left(660^{\circ} \mathrm{C}\right)$. The exothermic reaction of $\mathrm{AlN}$ formation induced the reaction between siliceous sand and $\mathrm{Al}$ to form $\mathrm{Si}$ and $\alpha \cdot \mathrm{Al}_{2} \mathrm{O}_{3}$. AlN $\cdot \mathrm{Al}_{2} \mathrm{O}_{3}$ was formed in the compacts heated at the temperature range of $660^{\circ}$ to $1200^{\circ} \mathrm{C}$. Si reacted with $\mathrm{N}_{2}$ to form $\beta^{\prime} \cdot \mathrm{Si}_{3} \mathrm{~N}_{4}$ above $1100^{\circ} \mathrm{C}$ and $15 \mathrm{R}$-AlN was also formed in the compacts heated above $1300^{\circ} \mathrm{C}$. Silica rich phases such as mullite, $\mathrm{O}^{\prime}$ and $\mathrm{X}$ phases were observed in the compacts which did not contain enough $\mathrm{Al}$ to reduce silica in the siliceous sand.

With increasing temperature, weight loss was observed and became considerable above $1400^{\circ} \mathrm{C}$. From the phase change in the compacts, the weight loss was considered to be mainly caused by the evaporation of $\mathrm{SiO}$ formed through the following reaction :

$$
\mathrm{Si}_{3} \mathrm{~N}_{4}+\mathrm{Al}_{2} \mathrm{O}_{3}=3 \mathrm{SiO}+2 \mathrm{AlN}+\mathrm{N}_{2}
$$

Mullite, $\mathrm{O}^{\prime}$ phase and $\mathrm{X}$ phase disappeared from the compacts when they were heated at $1500^{\circ} \mathrm{C}$ for about $27 \mathrm{~h}$. They were considered to be reduced by $\mathrm{CO}$ gas which was formed by the reaction between carbon material and oxygen present in $\mathrm{N}_{2}$ as impurity.

The weight loss kinetics at $1500^{\circ} \mathrm{C}$ followed parabolic rate law. The pore structure of the compacts seemed to have effect on the permeability of the gas phases. 
Key-words : Sialon, Siliceous sand, Al nitridation, Thermobalance

\section{1. 緒言}

著者らは，先にケイ砂とアルミニウム粉末から，直接 ち密なサイアロン焼結体を作る方法を見いだした ${ }^{1)}$ ここ の方法は, $1400^{\circ} \sim 1500^{\circ} \mathrm{C}$ での窒化反応過程と, $1600^{\circ} \mathrm{C}$ 以上の高温下におけるち密化過程に分けることができ る. $1400^{\circ} \sim 1500^{\circ} \mathrm{C}$ での窒化反応の過程は, サイアロン の焼結性及び最終サイアロン製品の組成及び物性を左右 する重要な過程である. それゆえ，著者らは先に、1500 ${ }^{\circ} \mathrm{C}$ までの昇温中における，ケイ砂とアルミニウムの混 合粉末の反応を調べ報告した ${ }^{2)}$ 。その実験において, 焼成 時の窒素ガス流量が少ない場合, 又注, 試料の成形圧が 高い場合には,アルミノテルミット反応 $\left(3 \mathrm{SiO}_{2}+4 \mathrm{Al}=\right.$ $\left.3 \mathrm{Si}+2 \mathrm{Al}_{2} \mathrm{O}_{3}\right)$ によって生成したケイ素の窒化が著しく 遅れた.このケイ素の窒化の遅れは, 窒素ガス中に含ま れる微量の酸素のために生成した酸化被膜が，窒素ガス の成形体内部への拡散を妨害することによるものと考え られた. そこで, 著者らは, 酸素のゲッターとして炭素 を用いたところ, ケイ素の窒化の進行のほかに, 約 1400 ${ }^{\circ} \mathrm{C}$ 以上で著しい重量の減少を認めた. $\mathrm{Jack}^{3)}$ はサイア ロンの生成には重量の減少が伴うことを報告しており, この重量の減少はケイ砂とアルミニウムからのサイアロ ンの生成に関して重要な現象であると考えられる.

本報告は，炭素が存在する窒素ガス中でのケイ砂とア ルミニウムの反応の過程で生じる重量減少の原因につい て, 主として熱天びんを用いて調べ，前報2)の結果と比 較して述べたものである。

\section{2. 実験}

\section{1 原料}

実験に用いたケイ砂（インド産，粒度 $1 \mathrm{~mm}$ 以下）及 び噴霧アルミニウム粉末（福田金䇴製，一200メッシ ユ）の化学組成を表 1 に示す。これらは前報2で用いた むのと同じものである.ケイ砂にアルミニウム粉末を 40, 50 及び $60 \mathrm{wt} \%$ それぞれ添加し，アルミナボール ミル中で 20 時間湿式（n-ブチルアルコール）混合粉砕 した.この混合粉末を $1 \mathrm{~g}$ ひよう量し, 金型ダイスを用 い, $400 \mathrm{~kg} / \mathrm{cm}^{2}$ の圧力下で直径 $10.5 \mathrm{~mm}$, 高さ約 $8 \mathrm{~mm}$ の円柱状に成形し, 熱天びん用試料とした. 更に, 同上 成形体を静水圧下で $1000 ， 2000$ 及び $3000 \mathrm{~kg} / \mathrm{cm}^{2}$ で成 形し, 同じく熱天びん用試料とした. なお, 成形体を 1:1 の塩酸で溶解し,アルミニウムの含有量を調べた
ところ，40，50 及び $60 \mathrm{wt} \%$ アルミニウム添加に対し 各々 $35.8 \mathrm{wt} \%\left(\mathrm{SiO}_{2}: \mathrm{Al}=1: 0.84 \mathrm{~mol}\right), 45.2 \mathrm{wt} \%$ (1 : 1.88)，56.0 wt\% (1:2.79) であったが，本報告中 ではアルミニウム添加量は 40，50及び $60 \mathrm{wt} \%$ と記し た.また,アルミニウム溶解後のケイ砂の粒度分布を光透 過式粒度分布測定装置で測定したところ，50\% 平均粒 度は $9.5 \mu \mathrm{m}$ であった.アルミニウムの粒度は，混合粉 末の走査型電子顕微鏡写真から，ケイ砂の粒度とほぼ同 ビ程度に粉确されたものと考えた.

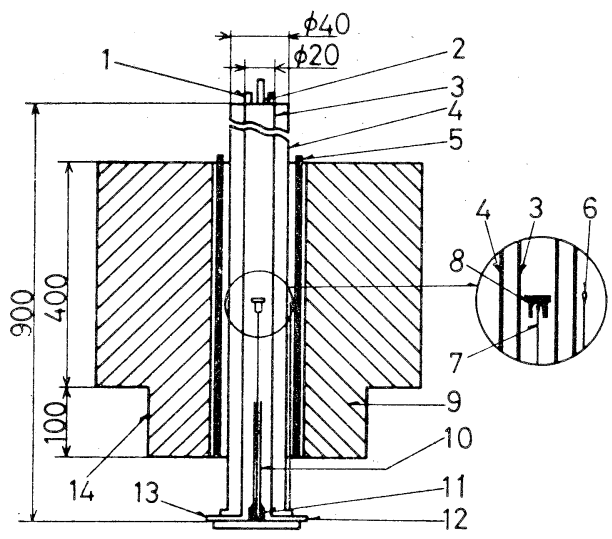

Fig. 1. Thermogravimetric apparatus for weight change measurement.

1,13: Cooling water, 2,12: Outlet and inlet of gas, $3:$ Inner tube (high alumina or carbon), $4:$ Outer tube (high alumina), $5:$ Heater $\left(\mathrm{LaCrO}_{3}\right), 6,7:$ Thermocouple (Pt6 Rh-Pt30 Rh), 8 : Specimen holder (high alumina), 9 : Insulator, 10,11: Silica tube, $14:$ Electric furnace.

\section{2 実験方法}

図1に実験に用いた熱天びん装置を示す。電気炉部 は，高温での対流による天びんのドリフトを防ぐため に, 内径 $40 \mathrm{~mm}$ のアルミナ管の内側に, 内径 $20 \mathrm{~mm}$, 長さ $800 \mathrm{~mm}$ の内管（図1の（3））が入っている．本実 験は，この内管を電極用黒鉛で製造し，酸素のゲッター として用いた・比較のため用いた前報の結果は内管にア ルミナ管を用いた場合のものである ${ }^{2)}$. 炉内を回転式真 空ポンプで約 $10^{-2}$ Torr に引いたあと, 超高純度窒素 (帝国酸素製 $\left[\mathrm{O}_{2}\right] \approx 10 \mathrm{ppm}$ ) を送大した. この操作を 3 回繰り返し炉内を窒素ふん囲気にした後, 昇温を開始し

Table 1. Chemical composition of siliceous sand and $\mathrm{Al}$ used as starting materials.

\begin{tabular}{ccccccccccccc}
\hline \multicolumn{4}{c}{ Siliceous sand } & \multicolumn{5}{c}{ Aluminium } \\
${_{2}} }$ & $\mathrm{Al}_{2} \mathrm{O}_{3}$ & $\mathrm{TiO}_{2}$ & $\mathrm{Fe}_{2} \mathrm{O}_{3}$ & $\mathrm{Na}_{2} \mathrm{O}$ & $\mathrm{K}_{2} \mathrm{O}$ & $\mathrm{Ig}$. loss & $\mathrm{Al}$ & $\mathrm{Si}$ & $\mathrm{Fe}$ & $\mathrm{Cu}$ & $\mathrm{Ni}$ \\
\hline 99.9 & 0.018 & 0.0023 & 0.0031 & 0.0022 & 0.001 & 0.03 & 99.75 & $<0.07$ & $<0.16$ & $<0.05$ & $<0.05$ \\
\hline
\end{tabular}


重量の変化を測定した。供給窒素ガス流量はほとんど $40 \mathrm{cc} / \mathrm{min}$ で行ったが，流量の影響をみる実験では，窒 素ガスを炉内に封入し, 一端を水閉した状態から, 流量 $70 \mathrm{cc} / \mathrm{min}$ まで変化させた。なお，窒素ガスは図 1 の （12）から入って管内を上方に流れ（2）上り流出する. 昇温速度は $5^{\circ} \mathrm{C} / \mathrm{min}$ と一定にし, 最高温度は $1500^{\circ} \mathrm{C}$ ま でとした．生成相の同定は，自動記録式 X線回折装置を 用い粉末法で以下の条件で行った $\left(\mathrm{Cu} \mathrm{K}_{\alpha}, 35 \mathrm{kV}-20\right.$ $\mathrm{mA}$ ，スリット幅 1-1-0.6 mm，黒鉛モノクロメーター 使用)。温度又は保持時間による生成相の変化は，ケイ 素 (111), $\beta^{\prime}-\mathrm{Si}_{3} \mathrm{~N}_{4}(200), \alpha-\mathrm{Al}_{2} \mathrm{O}_{3}$ (012), 窒化アルミニ

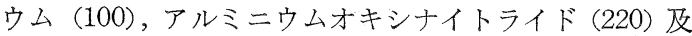
び 15 R-AlN (0015) 回折ピークの強度と，内部標準と して $10 \mathrm{wt} \%$ 添加した沈降性炭酸カルシウム（試薬特 級）の (101) 回折ピークの強度の比として測定した.

\section{3. 結 果}

\section{$3.11500^{\circ} \mathrm{C}$ まで昇温中の重量変化}

アルミニウム添加量 40，50 及び $60 \mathrm{wt} \%$ ，成形圧力 $400 \mathrm{~kg} / \mathrm{cm}^{2}$ で成形した試料について， $1500^{\circ} \mathrm{C}$ まで昇温 中の重量変化を図 22)（内管にアルミナを用いた場合） と図 3 (内管に炭素を用いた場合）に示す、いずれも， 窒素ガス流量 $40 \mathrm{cc} / \mathrm{min}$, 昇温速度 $5^{\circ} \mathrm{C} / \mathrm{min}$ で $1500^{\circ} \mathrm{C}$

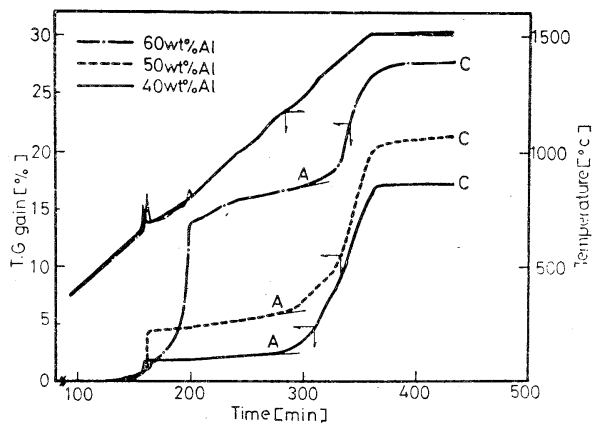

Fig. 2. Weight change of the compacts with temperature up to $1500^{\circ} \mathrm{C}$ in case of alumina tube.

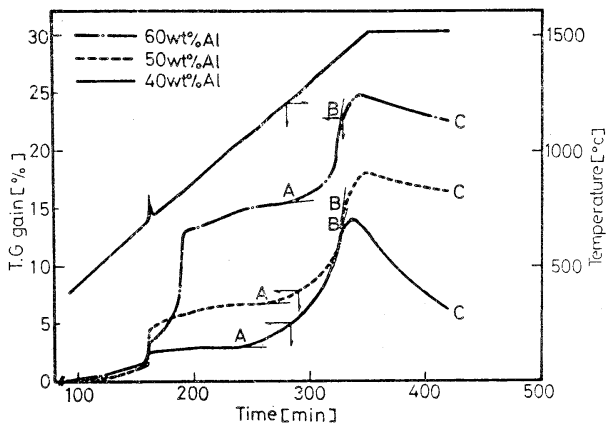

Fig. 3. Weight change of the compacts with temperature up to $1500^{\circ} \mathrm{C}$ in case of carbon tube.
まで加熱し，その温度に 1 時間保持したものである。

アルミナ管を用いた場合は，アルミニウム添加量によ って，重量変化曲線 はやや異なるが， $500^{\circ} \mathrm{C}$ 前後と約 $1150^{\circ} \mathrm{C}$ 付近からの重量増の 2 段階に分けられる. 昇温 中の試料を各温度で取り出し，X線回折により調べた結 果 ${ }^{2)}$, 約 $500^{\circ} \mathrm{C}$ からアルミニウムの窒化が始まり，約 $660^{\circ} \mathrm{C}$ でアルミニウムの窒化及びケイ砂とアルミニウム の閒でテルミット反応が急速に進行し，第1段階ではケ イ素， $\alpha$-アルミナ及びアルミニウムオキシナイトライド が生成することが分った．第 2 段階では，ケイ素の窒化 が始まって拉り, その窒化が始まる温度は, 添加アルミ ニウム量が増すにつれて高温側に移行したが，いずれも $1150^{\circ} \mathrm{C}$ 以上で $\beta^{\prime}-\mathrm{Si}_{3} \mathrm{~N}_{4}$ となった。アルミニウム及びケ イ素の窒化による重量の増加量は 40，50 及び $60 \mathrm{wt} \%$ のアルミニウム添加でいずれも，理論量の約 $95 \%$ であ った ${ }^{2}$. 一方，内管に炭素管を用いた場合，アルミニウ ムの窒化が始まる温度，アルミノテルミット反応が始ま る温度及びアルミニウムの窒化による重量増加量等，第 I段階の重量増の現象は，内管にアルミナを用いた場合 と比べほとんど変化は認められなかった。しかし，第 2 段階のケイ素の窒化が始まる温度は，いずれのアルミニ

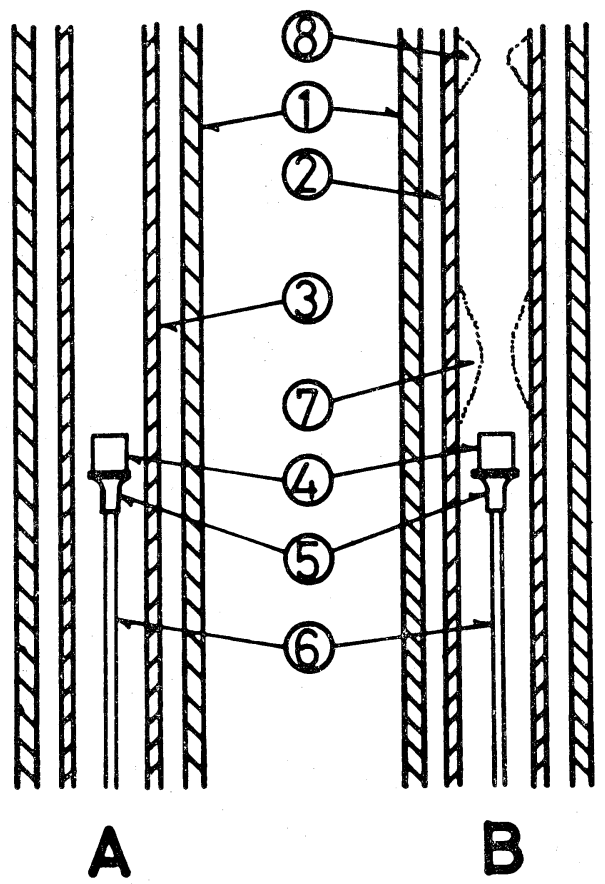

Fig. 4. Schematic illustration of the deposits in the TG furnace in case of alumina tube (A) and in case of carbon tube (B). 1: High alumina tube, $2:$ Carbon tube, 3: High alumina tube, $4:$ Specimen, 5 : Specimen holder (high alumina), 6 : TG holder unit (high alumina), 7 and $8:$ Fibrous deposits. 
ウム添加の場合も約 $50^{\circ} \mathrm{C}$ 低い傾向を示した. 更に，ど のアルミニウム添加の場合も $1400^{\circ} \mathrm{C}$ 以上になると著し い重量の減少が観察された. $1500^{\circ} \mathrm{C}, 1$ 時間保持後の各 試料の理論值に対する重量の増加率は，各々 33.4, 70.3 及び 78.1 でめり，これらの值は内管にアルミナを用い た場合の約 $95 \%$ と比較して著しく低い值であった。

\section{2 電気炉内部の析出物}

内管にアルミナを用いた場合, 熱天びん怇内の析出物 はほとんど認められなかったのに対し，炭素管を用いた 場合は炭素管内部に多量の析出物が認められた。図4に 重量減少の最む著しかった，40 wt％アルミニウムを添 加した試料を $1500^{\circ} \mathrm{C} て ゙ 27$ 時間加熱した時の炭素管内 の析出状況を模型的に示す. 管内には二つの位置に析出 物が観察された. すなわち, 試料の直上に析出した繊維 状析出物（図 4 の (7) ) 及び試料から約 $5 \mathrm{~cm}$ 上方に析 出した綿状析出物（図 4 の（8）である.図 5 に各々の 析出物の走查型電子顕微鏡写真を示方. 繊維状の析出物 （7） は X 線回折の結果 $\alpha-\mathrm{Si}_{3} \mathrm{~N}_{4}$ であり，その先端にビ 一ズが観察されることから，VLS機構礼によって析出し たものと考えられた，一方綿状の析出物 (8) は，X線回 折の結果 $\beta-\mathrm{Si}_{3} \mathrm{~N}_{4}$ と $\beta-\mathrm{SiC}$ からなっていた.これらの 析出物は, 3.1 節での重量の減少飞刘応して, $\mathrm{SiO}(\mathrm{g})$ が発生していることを示唆するものと考えられる，な お，これらの析出物の位置は，いずれも電気炉の均熱帯
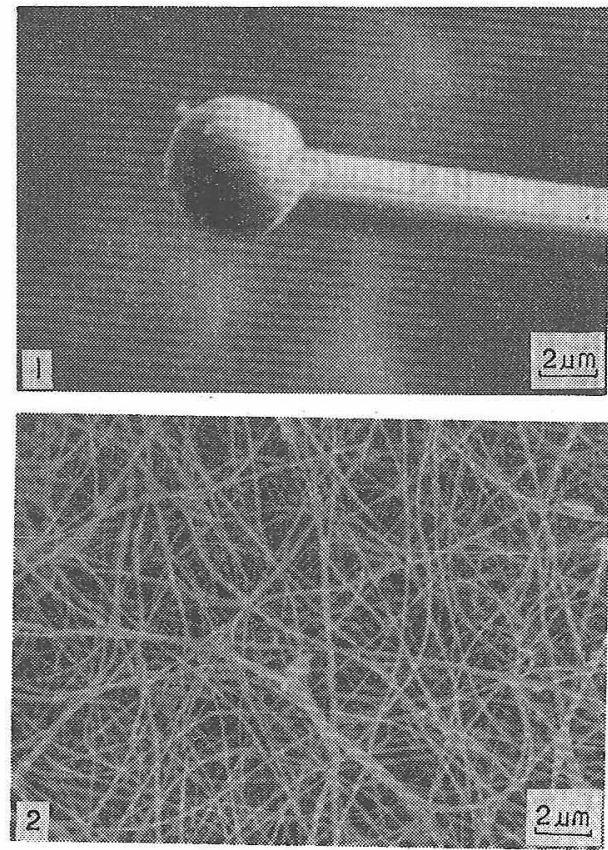

Fig. 5. SEM image of the fibrous deposits in the carbon tube.

$1: \alpha-\mathrm{Si}_{8} \mathrm{~N}_{4}$ fibre with bead on top of it (deposit (7) in Fig. 4).

$2: \beta-\mathrm{Si}_{3} \mathrm{~N}_{4}$ and $\beta-\mathrm{SiC}$ deposit (deposit (8) in Fig. 4).
に入っており，析出位置の閒の温度差は極めて少ないと 考えられる。

\section{3 組成の変化について}

図 6 は $1500^{\circ} \mathrm{C}$ まで昇温した時の試料を，各温度で取 り出して調べた組成の変化を模式的に示したもので,

3.1 節の図 2 に刘応している. 昇温時又は $1500^{\circ} \mathrm{C}$ まで の各温度に短時閒保持（約 1 時間以下）した場合注，炭 素管を用いた場合でもほとんど組成の差はなかった。

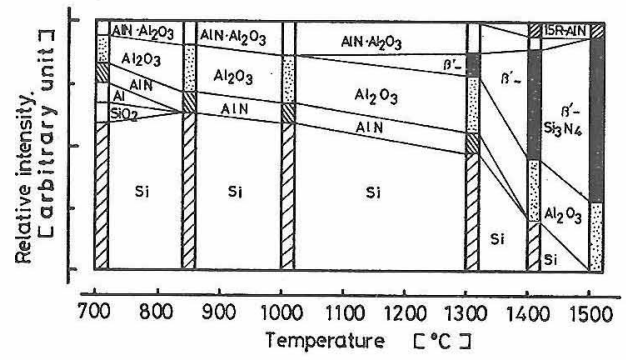

Fig. 6. Variation of each phase with temperature for the specimen of $50 \mathrm{wt} \% \mathrm{Al}$ addition. This figure shows the change of the relative intensity of each phase to the intensity of calcite which was added to the powdered specimen for $\mathrm{X}$-ray diffraction at constant weight as internal standard.

$\mathrm{CaCO}_{3}(101), \mathrm{Si}(111), \beta^{\prime}-\mathrm{Si}_{3} \mathrm{~N}_{4}(200), \alpha$. $\mathrm{Al}_{2} \mathrm{O}_{3}(012), \mathrm{AlN}(100), \mathrm{AlN} \cdot \mathrm{Al}_{2} \mathrm{O}_{3}(220)$, 15 R-AIN (0015).

図 3 での重量が減少することに伴った試料中の組成の 変化は， $1200^{\circ} \mathrm{C}$ 以上の各温度に長時閒（約 6 時間以上） 保持することによって明らかとなった. すなわち表 2 に $50 \mathrm{wt} \%$ アルミニウム添加した試料学約 $1200^{\circ} \mathrm{C}$ に 0 時 間及び 27 時間保持した場合，40，50,60 wt\%，アルミ ニウム添加した武料を約 $1500^{\circ} \mathrm{C} に 1$ 時間及び約 27 時 閒保持した場合の組成の变化を示す、試料中の各相の回 折強度は $10 \mathrm{wt} \%$ 添加したカルサイトの (101) 回折ピ 一クに対する相詨強度として測定したので, 表中の数字 の変化は各相の量の変化に対応していると考えることが できる. 例えば, $1200^{\circ} \mathrm{C}$ では, その温度に長時間保持 することにより，試料中のケイ素及び $\alpha$-アルミナが減少 し，窒化アルミニウムの生成が著しかった。 また，同上 組成の試料を $1500^{\circ} \mathrm{C}$ で約 27 時間保持すると, $\beta^{\prime}-\mathrm{Si}_{3} \mathrm{~N}_{4}$ 及び $\alpha$-アルミナが滅少し 15 R-AlN の生成が著しかっ た.この場合, $\alpha$-アルミナの減少と比べて $\beta^{\prime}-\mathrm{Si}_{3} \mathrm{~N}_{4}$ の減 少が著しいのが特徴であった.これらの傾向は, $40 \mathrm{wt} \%$ 及び $60 \mathrm{wt} \%$ アルミニウムを添加した場合もほぼ同様で あった. その他の組成の変化としては，40wt\% アルミ ニウムを添加し $1500^{\circ} \mathrm{C} に 1$ 時閒加熱した試料中のムラ イト， $O^{\prime}$ 相及び X 相等の silica rich 相が同温度に約 27時間保持することによって消滅することであった。 
Table 2. Variation of the phases with keeping time at $1200^{\circ} \mathrm{C}$ for $50 \mathrm{wt} \% \mathrm{Al}$ addition and at $1500^{\circ} \mathrm{C}$ for 40,50 and $60 \mathrm{wt} \% \mathrm{Al}$ addition in case of carbon tube. The numbers in the table represent X-ray intensity ratio of each phase to that of calcite which was added to the powdered specimen for X-ray diffraction at constant weight as internal standard.

\begin{tabular}{|c|c|c|c|c|c|c|c|c|c|c|c|}
\hline \multirow{2}{*}{$\begin{array}{c}\mathrm{Al} \\
\text { addition } \\
(\mathrm{wt} \%)\end{array}$} & \multirow{2}{*}{$\begin{array}{l}\text { Temp. } \\
\left({ }^{\circ} \mathrm{C}\right)\end{array}$} & \multirow{2}{*}{$\begin{array}{l}\text { Time } \\
\text { (h) }\end{array}$} & \multicolumn{9}{|c|}{ Phases } \\
\hline & & & $\underset{(111)}{\mathrm{Si}}$ & $\begin{array}{l}\beta^{\prime}-\mathrm{Si}_{3} \mathrm{~N}_{4} \\
(200)\end{array}$ & $\begin{array}{c}\alpha-\mathrm{Al}_{2} \mathrm{O}_{3} \\
(012)\end{array}$ & $\begin{array}{l}15 \text { R-AlN } \\
(0015)\end{array}$ & $\begin{array}{r}\text { AlN } \\
(100)\end{array}$ & $\begin{array}{c}\mathrm{AlN} \cdot \mathrm{Al}_{2} \mathrm{O}_{3} \\
(220)\end{array}$ & $\begin{array}{c}3 \mathrm{Al}_{2} \mathrm{O}_{3} \cdot 2 \mathrm{SiO}_{2} \\
(220)\end{array}$ & $\begin{array}{l}\mathrm{Si}_{2} \mathrm{ON}_{2} \\
(200)\end{array}$ & $\underset{(102)}{\mathrm{SiAlO}_{2} \mathrm{~N}}$ \\
\hline 50 & 1214 & 0 & 66 & 1.2 & 18.4 & - & 7.4 & 7.0 & - & - & - \\
\hline 50 & 1210 & 6 & 54 & 6.0 & 10.4 & - & 29.4 & - & - & - & - \\
\hline 50 & 1504 & 1 & - & 61.0 & 34.6 & 4.4 & - & - & - & - & - \\
\hline 50 & 1510 & 27 & - & 30.6 & 24.0 & 42.0 & - & - & - & - & - \\
\hline 40 & 1480 & 1 & - & 37.0 & 29.1 & - & - & - & 10.0 & 5.5 & 18.5 \\
\hline 40 & 1500 & 27 & - & 38.5 & 39.0 & 24.0 & - & - & - & - & - \\
\hline 60 & 1506 & 1 & - & 23.8 & 50.8 & 33.3 & - & - & - & - & - \\
\hline 60 & 1500 & 28 & - & 3.9 & 16.5 & 70.0 & 9.5 & - & - & - & - \\
\hline
\end{tabular}

\section{$3.41500^{\circ} \mathrm{C}$ での重量減少速度に対する窒素流量, 成} 形圧力及びアルミニウム添加量の影響

3.2 節及び 3.3 節の結果から, $1500^{\circ} \mathrm{C}$ における重量 の減少注として $\beta^{\prime}-\mathrm{Si}_{3} \mathrm{~N}_{4}$ と $\alpha$-アルミナが反応し $15 \mathrm{R}$ AlN 及び $\mathrm{SiO}(\mathrm{g})$ が生成することによるものと予想さ れた. 図7, 図8及び図 9 に $1500^{\circ} \mathrm{C}$ に打ける重量の減 少速度を窒素ガス流量, 成形圧力及びアルミニウム添加 量を変えて測定した結果を示す. 図 3 の重量の減少の形

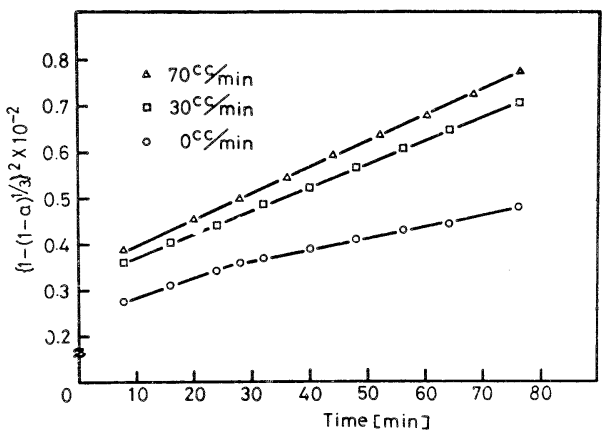

Fig. 7. Effect of $\mathrm{N}_{2}$ gas flow rate on weight loss kinetics analyzed by Jander's equation.

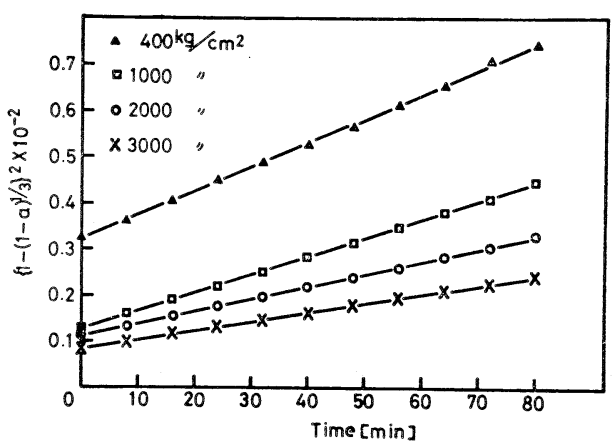

Fig. 8. Effect of forming pressure on weight loss kinetics analyzed by Jander's equation.

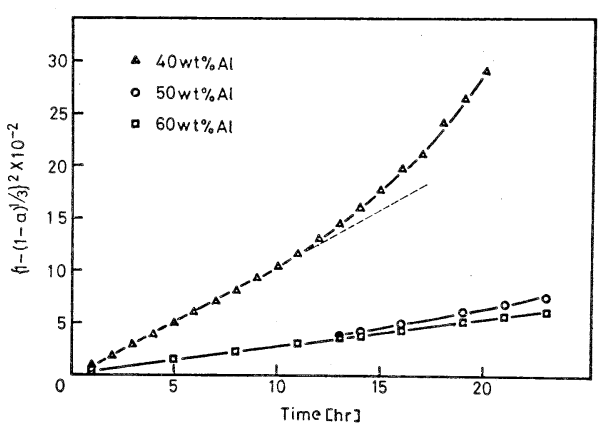

Fig. 9. Effect of $\mathrm{Al}$ addition on weight loss kinetics analyzed by Jander's equation.

から，重量の減少速度が放物線則に従うものと予想 ${ }^{5), 6)}$ し，各図とも下記に示す Jander ${ }^{7)}$ の式を用いてプロッ トしてある。

$$
\begin{aligned}
& \left\{1-(1-\alpha)^{1 / 3}\right\}^{2}=k t \\
& \alpha: \text { 反応率, } t: \text { 時間, } k: \text { 速度定数 }
\end{aligned}
$$

ここで反応率 $\alpha$ は, 測定した重量の減少量を計算で 求めた各試料中の $\mathrm{SiO}$ 量で除したものをとった. 図 7, 図 8 では，窒素ガス流量が $0 \mathrm{cc} / \mathrm{min}$ の場合の初期を除 き，いずれも良い直線が得られている.このことは， $1500^{\circ} \mathrm{C}$ における重量の減少速度は放物線則に従うこと, すなおち反応相又は生成相の拡散が律速過程であること を示している5),6).一方, 罒 9 のアルミニウム添加量の 影響では, 図 7 , 図 8 と同様に直線性が得られている が，40 wt％アルミニウムを添加した場合の重量減少速 度は他の二試料よりも大であること, 及び保持時間が約 12 時間以降では, 重量の減少速度は放物線則からずれ, 増加していることが特徵であった.

\section{4. 考察}

ケイ砂とアルミニウムの混合粉末の成形体を窒素ガス の通路に炭素が存在する状態で, $1500^{\circ} \mathrm{C}$ まで加熱した 時, 約 $1400^{\circ} \mathrm{C}$ 以上で急速な重量の減少が生じた.この 原因は, 窒素ガス中に炭素が存在するための効果と, 試 
料内部での反応によるものとが考えられた. 以下各々に ついて考察を試みる.

\section{1 炭素の効果}

加熱の際に固体状態で炭素が存在する効果は, 窒素ガ ス中の酸素分圧を次式に従って減ずることにあると考え られる。

$$
\mathrm{C}(\mathrm{s})+1 / 2 \mathrm{O}_{2}(\mathrm{~g})=\mathrm{CO}
$$

木島は8), 窒素ガス中の酸素化合物 species として, $\mathrm{H}_{2} \mathrm{O}, \mathrm{O}_{2}, \mathrm{CO}_{2}$ を考光, 常に炭素が固相で存在する状態 で加熱 し 各温度での酸素分圧を求め $1000 \mathrm{~K}$ で $p_{\mathrm{O}_{2}}=$ $5.4 \times 10^{-81} \mathrm{~atm}, 1500 \mathrm{~K}$ で $1.4 \times 10^{-23} \mathrm{~atm}, 2000 \mathrm{~K}$ で $3.3 \times 10^{-19} \mathrm{~atm}$ なる值を報告している。すなわち, 窒素 ガス中に固相の炭素が存在すると窒素ガス中の平衡酸素 分圧を下げるのに，非常に有効であることを示してい る. 本実験での系内の平衡酸素分圧 $\left(1500^{\circ} \mathrm{C}\right)$ む, 用い た窒素中の酸素濃度から考光約 $10^{-20} \mathrm{~atm}$ 以下になって いるものと考えられる.この平衡酸素分圧は Wildらの 平衡状態図 ${ }^{9}$ では, 窒化ケイ素の安定領域に入っている. これらのことから, 窒素ガス中に炭素が存在すること は，前報 2)に扮いて認められた試料の表面の酸素被膜の 生成を防ぎ，ケイ素の窒化を進行させるとともに，重量 の減少に関連して次節に述べる反応の進行を可能にして いるものと考えられる.

\section{2 試料中での反応}

昇温の過程で約 $1400^{\circ} \mathrm{C}$ 以上で認められた重量の減少 について考える. 重量の減少は, 昇温時には $1400^{\circ} \mathrm{C}$ 以 上で認められたが $1200^{\circ} \mathrm{C}$ 以上での各温度に長時間保持 することにより，既に生じている．これらの重量の減少 は, 3.4 節に扝ける試料中の組成の変化から猪股ら ${ }^{10)}$ 及 び Messier ら ${ }^{11}$ が報告した以下の反応によることが考え られた。

$$
\begin{aligned}
& 3 \mathrm{Si}+\mathrm{Al}_{2} \mathrm{O}_{3}+\mathrm{N}_{2}=3 \mathrm{SiO} \uparrow+2 \mathrm{AlN} \\
& \mathrm{Si}_{3} \mathrm{~N}_{4}+\mathrm{Al}_{2} \mathrm{O}_{3}=3 \mathrm{SiO} \uparrow+2 \mathrm{AlN}+\mathrm{N}_{2} \\
& \beta^{\prime}-\mathrm{Si}_{3} \mathrm{~N}_{4}+\mathrm{AlN} \rightarrow 15 \mathrm{R}-\mathrm{AlN}
\end{aligned}
$$

すなわち, 約 $1200^{\circ} \mathrm{C}$ 近辺では, ケイ素の窒化速度が 遅いため主として (2) の反応によって重量の減少が進行 すると考えられた。 また $1500^{\circ} \mathrm{C}$ 近辺すなわち, ケイ素 の窒化が昇温時に終了した段階では, 重量の減少は主と して（3）式により進行し $\mathrm{SiO}(\mathrm{g})$ と窒化アルミニウム を生成するものと考えられた. (3) 式で生成した窒化ア ルミニウムは直ちに $\beta^{\prime}-\mathrm{Si}_{3} \mathrm{~N}_{4}$ と反応し $15 \mathrm{R}-\mathrm{AlN}$ とな り, 安定したものと思われる. また，40\% アルミニウ ムを添加した試料では， $1500^{\circ} \mathrm{C} に 27$ 時間加熱すること によりムライト， $\mathrm{O}^{\prime}$ 相及び $\mathrm{X}$ 相が消滅した。これは窒 素ガス中の酸素が (1) により CO ガスとして固定され るためムライト， $\mathrm{O}^{\prime}$ 相及び $\mathrm{X}$ 相を構成する $\mathrm{SiO}_{2}$ が $\mathrm{SiO}(\mathrm{g})$ として還元されるためと考えられた. したがっ て図 3 に打ける $40 \%$ アルミニウムを添加した試料中で
の重量減少は（3) 式による重量の減少と上述の理由によ る重量減少が並行して生じているものと考えられた.

\section{3 重量の減少速度について}

3.4 節の結果から， $1500^{\circ} \mathrm{C}$ における重量減少速度は放 物線則に従うものと考えることができよう。しかし，現 段階では具体的な律速段階は明らかでない，本実験の場 合, 重量の減少速度が窒素ガス流速及び成形圧力によっ て影響を受けることから，成形体内の pore structure は 反応の進行にとって, 重要な要因であると考えられる. 例えば，同一試料の外周部と内部の組成の差を調べる と，外周部の方が 15 R-AlN の生成量が多いこと，また 前報の実験2)で，ケイ素の窒化が外周部から同心円状に 進行したことは，試料内の通気性が重要であることを示 している.このことから, 図 9 での $40 \%$ アルミニウム を添加した試料で約 12 時間以降でみられた重量の増加 は， pore structure の変化に帰することができると考え ている。

\section{4 炉内の析出物について}

熱天びん炉内には二つの位置に析出物が認められた。 すなわち，試料の近辺に析出した $\alpha-\mathrm{Si}_{3} \mathrm{~N}_{4}$ 及びそれより 約 $5 \mathrm{~cm}$ 上方に析出した $\beta-\mathrm{Si}_{3} \mathrm{~N}_{4}$ と $\beta-\mathrm{SiC}$ の混合物で ある.これらの析出機構については，以下の反応を考え ている12).

$$
\begin{aligned}
& 3 \mathrm{SiO}+3 \mathrm{C}+2 \mathrm{~N}_{2}=\alpha-\mathrm{Si}_{3} \mathrm{~N}_{4}+3 \mathrm{CO} \\
& \mathrm{SiO}+2 \mathrm{C}=\beta-\mathrm{SiC}+\mathrm{CO} \\
& \mathrm{SiC}+2 \mathrm{SiO}+2 \mathrm{~N}_{2}=\beta-\mathrm{Si}_{3} \mathrm{~N}_{4}+\mathrm{CO}_{2}
\end{aligned}
$$

すなわち，(2)，(3) 式又は silica rich 相の還元によ り生成した $\mathrm{SiO}(\mathrm{g})$ は，炭素管と反応して（5）式によ り $\alpha-\mathrm{Si}_{3} \mathrm{~N}_{4}$ を生成するものと考えた. 更に $\mathrm{SiO}$ 注，(6) により $\beta-\mathrm{SiC}$ を生成し， $\beta-\mathrm{SiC}$ は (7) 式により $\beta-\mathrm{Si}_{3} \mathrm{~N}_{4}$ を生成したものと考えた。

\section{5. ま と め}

ケイ砂とアルミニウム粉末の成形体を炭素の存在する 窒素ガス中で最高 $1500^{\circ} \mathrm{C}$ まで加熱し， $1400^{\circ} \mathrm{C}$ 以上で重 量の減少を認めた. 加熱中の重量の変化及び生成相の変 化を調べ以下の結果を得た。

(i) 窒素中存在する炭素は $\mathrm{C}+1 / 2 \mathrm{O}_{2}=\mathrm{CO}$ の反 応により窒素ガス中の酸素分圧を約 $10^{-20} \mathrm{~atm}$ 以下に下 げるとともに，酸素を一酸化炭素として固定する。その ため,アルミナ管を用いた場合生成した酸化被膜は, カ 一ボン管を用いた場合は認められなかった。

（2） $1400^{\circ} \mathrm{C}$ 以上で認められた重量の減少は，試料 中で以下の反応が進行し， $\mathrm{SiO}(\mathrm{g})$ が生成するためと考 えられた。

1) ムライト， $O^{\prime}$ 相及び $X$ 相等の silica rich 相 の一酸化炭素による還元.

2）窒化ケイ素と $\alpha$-アルミナの反応による $\mathrm{SiO}(\mathrm{g})$ 
の生成.

（3） $1500^{\circ} \mathrm{C}$ における重量の減少速度は, 放物線則 によく適合した。具体的な律速段階は不明であるが，試 料中の pore structure が重量減少速度に, 影響をもつこ とが明らかとなった。

(4) 炭素管の内部には, $\alpha-\mathrm{Si}_{3} \mathrm{~N}_{4}$ 繊維と $\beta-\mathrm{Si}_{3} \mathrm{~N}_{4}$ 及 び $\beta-\mathrm{SiC}$ の混合物の析出が認められた.これらは重量の 減少に伴って生成した $\mathrm{SiO}(\mathrm{g})$ が，炭素管と以下のよう

に反店し生成したものと考えられた.

$$
\begin{aligned}
& 3 \mathrm{SiO}+3 \mathrm{C}+2 \mathrm{~N}_{2}=\alpha-\mathrm{Si}_{3} \mathrm{~N}_{4}+3 \mathrm{CO} \\
& \mathrm{SiO}+2 \mathrm{C}=\beta-\mathrm{SiC}+\mathrm{CO} \\
& \mathrm{SiC}+2 \mathrm{SiO}+2 \mathrm{~N}_{2}=\beta-\mathrm{Si}_{3} \mathrm{~N}_{4}+\mathrm{CO}_{2}
\end{aligned}
$$

$$
\text { 文献 }
$$

1) S. Umebayashi and K. Kobayashi, Am. Ceram. Soc.
Bull., 56, 578-79 (1977).

2）梅林正気, 小林和夫, 窯協, 86, 449-57 (1978).

3) K.H. Jack, J. Mater. Sci., 11, 1135-58 (1976).

4) R.S. Wagner and W.C. Ellis, J. Appl. Phys., 4, 89 (1964).

5) H.D. Batha and E.D. Whitney, J. Am. Ceram. Soc., 56, 365-69 (1973).

6) D.R. Messier and P. Wong, J. Am. Ceram. Soc., 56, 480-85 (1973).

7) W. Jander, Z. Anorg. Allg. Chem., 16, 1 (1927).

8）木島, “無機材質研究所報告第 13 号”, 科学技術庁, (1972) p. 8-9.

9) S. Wild, P. Grieveson and K.H. Jack, Special Ceramics, 5, 271-84 (1972).

10）猪股吉三, 雪野 健, 和田寿璋, 箘協, 84, 254 (1976).

11) D.R. Messier and G.E. Gazza, J. Am. Ceram. Soc., 58, 538-40 (1975).

13) 元井操一郎, 電化, 45, 181-85 (1977).

論文・Paper

\title{
The Composition of Mullite Like Compound Appeared in $\mathbf{S i}-\mathbf{A l}-\mathbf{O}-\mathbf{N}$ System
}

\author{
Yoshizo INOMATA, Akira ONO, Yasutoshi HASEGAWA \\ and Yoshiyuki YAJIMA \\ (National Institute for Researches in Inorganic Materials, Niihari-gun 300-31)
}

\begin{abstract}
Composition of the mullite like compound (often called as X-phase in $\mathrm{Si}-\mathrm{Al}-\mathrm{O}-\mathrm{N}$ system) were studied by the following experiments.

(1) Correspondence between the composition of raw mixture and formed compound after hot-pressing the mixture at $1700^{\circ} \sim 1820^{\circ} \mathrm{C}$.

(2) Analytical results of the X-phase with E.P.M.A. and wet chemical analysis.

(3) Correspondence between X-ray diffraction data collected with a "single" crystal of the X-phase and the analytical results.

From the results of those experiments, it was concluded that the $\mathrm{X}$-phase has very close composition to that proposed by L.J. Gauckler et al., $\mathrm{Si}_{4} \mathrm{Al}_{4} \mathrm{O}_{11} \mathrm{~N}_{2}$. The atomic ratio, $\mathrm{Al} / \mathrm{Si}$ was considered to be variable in a range, $1.0 \sim 1.8$, but the ratio N/O was considered to be in fairly narrow range, $0.17 \sim 0.18$ at about $1700^{\circ} \mathrm{C}$. Typical compositional formula, $\mathrm{Si}_{6} \mathrm{Al}_{7} \mathrm{O}_{18} \mathrm{~N}_{3}$ was proposed for the X-phase under fully occupied state.
\end{abstract}

[Received November 30, 1978]

\section{Si-Al-0-N 系に現れるムライト様化合物の組成}

\author{
猪股吉三・小野 晃・長谷川安利・矢島祥行 \\ （科学技術庁 無機材質研究所）
}

Si-Al-O-N 系に現れるムライト様化合物（この系でしばしば X 相と呼ばれる）の組成を次の 実験により検討した。

（1）原料組成とこれを $1700^{\circ} \sim 1820^{\circ} \mathrm{C}$ 亿加圧焼結して生成した化合物との対応. 